\title{
Lessons Learned from Books about the Amish: Part II
}

\author{
Joseph F. Donnermeyer \\ Emeritus Professor/Academy Professor \\ School of Environment and Natural Resources \\ The Ohio State University \\ donnermeyer.1@gmail.com
}

Submitted October 5, 2020; accepted December 2, 2020; published March 24, 2021

https://doi.org/10.18061/jpac.v1i2.7954

$\mathbf{I}_{\mathrm{a}}^{\mathrm{t}}$ is always possible to learn new things from every book read, even if the same subject was read about many times before. Part II of "Lessons Learned from Books about the Amish" is a case in point. Having read dozens of books and, I should add, hundreds of peer-reviewed journal articles and book chapters about the Amish, one might think I would be thoroughly bored reading more. Yet, none of the 11 books (including the six reviewed in Part I, published in the inaugural issue of $J P A C$ ) put me in the doldrums. From each, including the final five, there are many lessons to be learned. To remind the reader, a lesson for me as defined in Part I is anything found in these books that I could use to revise and rewrite a lecture for either my online Amish Society class, or for the residential version, once the COVID-19 pandemic is over and I am allowed back into the classroom.

The five books in Part II include Steven Nolt's The Amish: A Concise Introduction, Sam Stoltzfus's What It's Like to be Amish, Melissa Thomas's Life Through Their Lens: A Photo Collection by Amish and Mennonite Communities, Volume 1, Erik Wesner's Success Made Simple: An Inside Look at Why Amish Businesses Thrive, and Marcus Yoder's Cathedrals, Castles, Caves: The Origins of the Anabaptist Faith. They are presented in alphabetical order. Any other order of presentation might suggest I judged certain ones to be better or superior to the others. That is not my intent. From each book, I learned a great deal, but limit my review here to three lessons each.

Nolt, Steven. The Amish: A Concise Introduction. Baltimore: Johns Hopkins University Press. 2016.

Recently, I was asked to develop a noncredit outreach/continuing education course about the Amish for The Ohio State University. Immediately, recommendation of the Nolt book as the primary text came to my mind because it is easy to read and less than 150 pages in length. Yet, it is chock-full of straightforward and reliable information about Amish society. There are thicker books, longer books, and books with far more detail, but for an introduction, this book is as good as it gets.

What three lessons from the Nolt book could I use to write my lectures for a noncredit version of Amish Society? First, students must have at least an elemental sense of the Anabaptist movement from which the Amish arose, especially various formative events in Europe associated 
with the onset of the Protestant Reformation and subsequent events throughout the sixteenth and seventeenth centuries. Without a sense of history, a fundamental understanding of the Amish today is impossible, in my estimation. Furthermore, even though there are specific and significant events in Anabaptist (and Amish) history that seem transformative, I make the point several times in my lectures that "history is mostly evolution, with an occasional revolution." In other words, the fundamental characteristics of all societies took time to develop. Amish society is not like a frozen dinner heated up in the microwave, but rather history is a product of continuous adjustments (and therefore, continuous change) over a very long period of time.

The second lesson is one already mentioned - in the book by Lester Beachy reviewed in Part I. It is Nolt's Chapter 5 about rumspringa, and it is aptly subtitled "Amish Gone Wild?" It is the question mark that makes this chapter a must read for beginning students enrolled in an outreach/continuing education course. As both Beachy and Nolt emphasize and put into perspective: beware of romance novels and reality shows, for they never portray the Amish accurately! They are merely ways for authors and cable show producers to pay for the rent on their Malibu homes and the gasoline for their Hummers.

The third lesson from Nolt's book is found in Chapter 8, "The Amish and Their Neighbors." This is a chapter I want students to read twice in order to understand that the boundaries between Amish society and culture and the larger, mainstream culture of North American society are so porous that one could make the argument that there are no boundaries at all between the two. Indeed, there are many points of distinction, with almost all based on interpretations of religious beliefs or on the ways that the Amish deal and negotiate with the non-Amish, especially various levels of government in Canada and the United States. To portray the Amish as a closed society shut off from the modern world is simply wrong, and even to paint a picture of the Amish as only reluctantly open to influences from the outside is to sketch something more akin to abstract art than realism.

\section{Stoltzfus, Sam S. What It's Like to be Amish. Lancaster, PA: Walnut Street Books. 2018.}

Like the book by Lester Beachy, this book is written by a lifelong member of the Amish community. Like the Marlene Miller book, it is a series of short autobiographical chapters. Unlike the Miller book, it is a series of lighthearted but insightful narratives of Mr. Stoltzfus's experiences growing up and living in the Greater Lancaster County, Pennsylvania, settlement, which is one of the two largest in the world today and the oldest continuous Amish community.

The first lesson from this book is how much we can see the ways North American society has changed, both for the Amish and the non-Amish, as seen through the experiences of an Amish person. These lifelong experiences are the foundation for a lecture on understanding social change in Amish society. It seems impossible to me to teach a course titled "Amish Society" without a focus on social change. How much Canada and the United States have changed since colonial days is the backdrop by which to talk more specifically about the Amish over their nearly 300 years in North America. For example, by 1917 in the United States and about 1925 in Canada, the majority 
of their respective populations lived in cities, not in the country or on farms (World Bank, 2019). The adoption of motor vehicles and all the technologies that came with electrification rapidly changed mainstream North American society and created a greater distance between mainstream and Amish lifestyles. Without appreciating these broader, society-wide changes, change within Amish society, as illustrated in many of Stoltzfus's humorous stories, may be good for a chuckle or two, but are read in a historical, social, and cultural vacuum, without context.

Perhaps the most enjoyable and readable chapter in Sam Stoltzfus's book is Chapter 19, "The Responsibility of Being Amish Parents." His lighthearted, Mark Twain-like observations are ideal for teaching a lesson to students about family life. Consider, for example, the section of Chapter 19 titled "First Baby Shock." To quote: "We became quickly aware that Amish babies are just like all babies - they don't come with instructions" (p. 119). This quote can be read at two levels. The first and most obvious is that all babies need the same basic care, no matter within what culture anywhere in the world they are born. However, at a second level, what Stoltzfus just told the reader is that for the baby to grow up and decide to be Amish requires a thorough socialization into Amish religious beliefs and values. There is no genetic code to explain Amishness, only cultural conditions. Babies do not come with instructions; hence, family, church, and community step in to provide the necessary blueprint.

The third lesson comes near the end of the book, Chapter 31, specifically. It is titled "Life in God's Hands," and begins with the trauma of an accident when a too-drunk motorcyclist driving far over the speed limit collided with the Stoltzfus buggy. Buggy accidents are common on rural roads, with the great differences today in speed between motor vehicles and buggies. Aside from the physics of speed differentials and braking distances, the chapter itself is a reminder of the human side of these accidents. Horses and people are injured and killed, and even though some would say the Amish are fatalistic about accidents, viewing them as "God's will," there is still the emotional injury they cause for the family and for the community. As the Amish population grows and new settlements are continuously founded, this chapter is a lesson that should remind students that the Amish are thoroughly enmeshed in the larger North American society. Toward the end of my Amish Society course, I present two lectures, back-to-back, titled "Symbolic Separations" and "Symbolic Associations." The latter emphasizes the recent growth of health care, road safety, and other organizations that work collaboratively with the Amish today, even though collaborations between the Amish and the non-Amish go back to the first day the Amish arrived in North America in the early eighteenth century, and before that, to the assistance provided by the treuherzige in the days of persecution in Switzerland and surrounding regions (Nolt, 2016).

\section{Thomas, Melissa. Life Through Their Lens: A Photo Collection by Amish and Mennonite Communities, Volume 1. Whipple, OH: Center for Appalachia Research in Cancer Education. 2018.}

In physical terms, this is the largest of the 11 books in three-dimensional space (height/thickness, length, and width), but the smallest in words. As the title clearly states, it is a book of pictures and 
quotes, not narrative. Nonetheless, it is difficult to limit a description of this book to only three lessons that inform my lectures, because there are so many more.

First, some background on the author: Melissa Thomas is the founding director of the Center for Appalachia Research in Cancer Education (CARE), whose headquarters are not too far from the Amish \& Mennonite Heritage Center (see reviews of the Lester Beachy and Marcus Yoder books). Both are in the middle of the large Greater Holmes County, Ohio, Amish settlement. Thomas and her colleagues organize a biennial Amish health conference, usually attended by about 150 health care professionals. All proceeds from this beautiful picture book go to fund the women's health programs and services to Amish and Mennonite women. CARE itself is a great example of a symbolic association or link between the Amish and non-Amish.

The first lesson from this book for me is found on page 16. There is a black-and-white photo of a woman in a dairy barn and the hind ends of six bovines, all with udders that look like they are ready to be milked. The quote on the opposite page (15) states the following: "Women are not just stuck in the house doing dishes - they're also out there with their husbands making a living, especially farm women. We work with the animals - and we help make the decisions."

There is actually a double lesson in this quote. First, the stereotype of Amish women as subordinate to their husbands is belied by what they actually do to contribute to their families, and to the church and community as well. This quote is an opportunity to counteract highly inaccurate misperceptions that Amish wives are passive and without a voice, an absurdity that is nearly as extensive in cheesy media reports and bad romance novels as popular views of rumspringa. I use it to inoculate my students against the popularized forms of gendered typecasting of the Amish to which they will be subjected long after I submit their final grades for my course. As well, this quote shows that the transition from agriculture to nonfarm jobs has an impact on relationships within the family, both between husbands and wives and between parents and children.

The second lesson that I use from this book is located on pages 32 and 33. There is a beautiful full-color photo of an Amish farm, including a man driving a team of horses hitched to what looks like a manure spreader down the lane to the house, a woman with a broom sweeping along the lane (presumably to push what wasn't spread on the field out of the way), and two houses on the property, one of which (I presume) is the grandparent or dawdy house. There is enough detail in this one picture alone to create lectures for a full week of my course; however, it is a quote that is the focus on the lesson I learned from Life Through Their Lens. Here is what it says:

We have a fire fund.... We list and evaluate everything we own that can be destroyed. As money is needed for a building that has burned, we pay one dollar per thousand dollars of value into the fund.... Each district has appraisers who will decide the value of the loss. The treasurer of the fund pays the farmer seventy-five percent of the value he lost. We have had this system as long as there have been Amish in this community. No one makes a wage or profit off that money, and it has worked great. 
This lesson is also not about merely one thing, but about three things. First, it demonstrates the tradition of a more collectivistic and less individualistic way of life. Second, it illustrates a symbol of separation - no reliance on government or private insurance. The community is self-insured and there is no need to make the insurance rates high because the assessor is not paid, unlike private insurance where a large percentage of the premiums goes to pay for the luxurious lifestyle of the company CEO. Third, it is a perennial feature of Amish community life to search for ways to be more self-reliant to maintain their distinctiveness from the mainstream. All three of these sublessons illustrate the distinctiveness of the Amish as a religious subculture.

Finally, there is, on pages 52 and 53, a black-and-white picture of an Amish woman in the basement of a house reaching toward a shelf filled with preserved food, almost all in quart containers. Each shelf is festooned with handwritten labels, which are more easily read with a magnifying glass - from peaches to dill pickles. Only one of the glass jars appears to have been bought at a supermarket, and the top shelf is filled with pint-size glass containers and quart jars yet to be filled with good food for consumption during the colder months of the year. The quote accompanying this picture is as follows:

Being in the pantry is just like an everyday thing for us - it represents a lot of time and a lot of work. Just think, from that real tiny seed that you plant- - what you get out of it... These days, most people just go to the store and buy groceries. We know where ours came from.

Even though the Amish have transitioned out of farming to a great extent, it is still true that most have a direct connection to the land, vis-à-vis a garden. A garden is the purview of the wife more than the husband. Even though the picture and quote say something about the division of labor in an Amish family, that is not the lesson I derive from pages 52 and 53. It is the difference between the Amish and mainstream North American society, and how far the mainstream has changed in the past 100 years plus two decades. Less than $1.5 \%$ of the population of Canada and the United States live on farms (Lepley, 2019), and almost half of the money people spend on food is now spent at restaurants (U.S. Bureau of Labor Statistics, 2016). Hence, not only do most North Americans not directly grow their own food, they do not even see it prepared (only served). Their first direct encounter with food is when the fork leaves the plate and is lifted toward an open mouth by the hand holding the utensil. Pages 52 and 53 contain an illustration of social change, which in this case is the growing differences between Amish lifestyles and the lifestyles of most mainstream North Americans through the illustration of growing, canning, and preserving food. 


\section{Wesner, Erik. Success Made Simple: An Inside Look at Why Amish Businesses Thrive. San Francisco: Jossey-Bass. 2010.}

Erik Wesner should be a familiar name to many readers of this review essay, because he is also the person who publishes Amish America (https://amishamerica.com). This website is often the first with breaking news stories about the Amish, from the tragic, such as the kidnapping of Linda Stoltzfoos and fatal buggy accidents, to new trends, such as Amish in the Conewango Valley settlement of southwest New York reacquiring control of a cheese-making plant as a response to low prices for Grade A milk. Simply, there are many interesting stories to be found on the Amish America website, from photo tours inside Amish houses in various settlements to summaries of studies about the Amish, such as of Amish settlement growth.

Wesner's book stems in part from his many visits to Amish settlements throughout North America. It began when he was a bookseller for the Nashville Southwestern Company and his first encounter with Amish who were "conversing in a language that's clearly not my own" (p. xiii). To quote again: "Some five years, twenty settlements, and five thousand Amish homes later, the Amish don't seem so odd anymore." Hence, the book is about what Don Kraybill described in the foreword: "A surprising thing happened across America in recent years: many Amish farmers abandoned their plows to become entrepreneurs. And they succeeded" (p. ix). This comment reflects the first lesson from the Wesner book that informed the development of my Amish Society course lectures. It is a book about the transition of the Amish over less than a half century, from a religious sect whose economy was mostly agriculture-based to one that is now amazingly diversified. It is one of what I regard as four fundamental changes in Amish society, along with rapid population growth, increased number of new settlements founded every year, and increase in percentage of girls and boys born to Amish families who decide to be baptized Amish once they reach the age of decision. Hence, Wesner's book can be read as how the Amish have learned so much about running non-agricultural businesses during this transition, a transition that is now more than one generation old. However, keep in mind that the Amish maintain a strong sense of identity with their agricultural heritage, and that the number of Amish farmers is actually increasing, but not at the same pace as population growth. The result is that a growing proportion of Amish men do not farm, and those who do are specializing more and more in fresh produce and greenhouse products or raising animals such as goats, sheep, and ducks instead of dairy cows.

The second lesson from Wesner's book is the most important for my Amish Society lectures. It is this: throughout his many anecdotes about Amish businesses and quotes from Amish businesspeople (mostly men, but also women), Wesner depicts a very normal business rationality, but with an Amish touch. One of the best is found on pages 114-115 where he poses a hypothetical example of a non-Amish, college-educated young adult who was looking for a job, but not the entry-level task of sweeping floors. The Amish business owner of a company that makes gazebos replied, "If he's not dignified enough to pick up that broom, he wouldn't be dignified enough to

work for me." Throughout Success Made Simple, the Amish stamp on business rationality, and the difference with the corporate climate of businesses in mainstream North America, is apparent. 
There is much less inequality between workers and management among the Amish, and a much greater chance that an Amish business owner has done everything from sweeping the floors to maintaining the company's financial ledger. It is the more communal, collectivist nature of Amish businesses, along with their success, as Kraybill pointed out in the foreword, that shows how a subculture adapts to and reinvents an influence that came mostly from the outside.

The final lesson of this book also says something about the distinctive features of Amish society and cultural values. It can be found on pages 185 and 186, where Wesner discusses Amish viewpoints on the appropriate size of a business. The various quotes clearly show that bigger is not better. In fact, there is an almost Goldilocks view (not too big, not too little) in these quotes. For example, this short section ends with the following observation by an Amish businessman: "It's hard to be just right with enough orders." I can still remember a very successful Amish businessman from the Greater Holmes County settlement replying to one of my Amish Society students during a field trip when asked about his plans to expand: "I won't go much beyond 18 workers. If more orders come in, I'll help someone else start a business making the same things." I remember thinking, "This is not mainstream capitalism, it is capitalism with an Amish twist." No worries about monopolies in Amish society!

\section{Yoder, Marcus A. Cathedrals, Castles, Caves: The Origins of the Anabaptist Faith. Winesburg, OH: JPV Press. 2017.}

Marcus Yoder is the executive director of the Amish \& Mennonite Heritage Center (AMHC) and the Ohio Amish Library, which are near Berlin and at about the geographic center of the Greater Holmes County settlement. It is the place where the Behalt Cyclorama is located. The cyclorama is a 10 -foot-high by 265 -foot-long painting depicting the history of the Anabaptist movement since its origins in early sixteenth-century Switzerland. The painting, by Heinz Gaugel (1927-2000), should be on the bucket list of anyone who enjoys a trip to the rural environs of Holmes County.

Yoder earned a bachelor's degree in history from The Ohio State University and a master's degree in the history of Christianity from Yale University. The book shows how well-versed he is in the development of Anabaptism over the many centuries. However, it is a straightforward and easy-to-follow book, with a style similar to that of the author of the first book in this review, Lester Beachy, who also worked at AMHC. Each of the book's 26 chapters is focused on a very specific topic, narrated in only a few pages, and accompanied by maps, pictures, and other graphics. There is at least one lesson in each chapter suitable for developing a lecture for my Amish Society students. However, here are my three favorite ones.

First, there is no better way to frame historical events, especially their chronological linkages, than timelines. This book has four, one for each of the sections into which the 26 chapters are organized. The sections begin with these timelines, which is a great way to organize specific historical events and to show a pattern that puts the events into a proper context. As well, it reinforces the idea that "history is mostly evolution, with an occasional revolution," previously 
mentioned in my comments on the Nolt book. Hence, the timelines add great value to the specific chapters by helping to create historical context.

The second lesson for me is the maps, found on pages 87 and 98, of Germany in the 1500s and Switzerland in 1513, respectively. Back then, Germany was a mishmash of principalities, kingdoms, city-states, and other divisions. Switzerland was a confederation of autonomous cantons or governmental divisions, organized for mutual protection. Historical context is everything because it helps us understand that the Anabaptist movement, as an "earnest endeavor to get back to the scriptures," as Lester Beachy says it, occurred in a real-world context of political, religious, and economic division. Europe can be described at that time as in the middle of a very violent religious and political civil war. Yoder's timelines and maps helped me to write a lecture for my online version of Amish Society that starts out with the following:

We often think of history as a very boring chronology of events and trivialities of little relevance to the way we live today, but for those involved in the early days of the Protestant Reformation and the Radical Reformation, they were days of fervent debates, hard choices about religious beliefs and practices, and decisions that might result in a prison sentence, torture, or even death. The story about how the Amish sect developed in Europe over a span of two centuries is indeed one of debate, choice, imprisonment, and martyrdom. Hardly boring stuff!

Finally, Yoder presents many interesting facts, interesting for me because either I forgot I knew them or because I never knew them. These facts, including the following narration by Yoder of the execution of one of the original leaders of the Radical Reformation, helped me revise my lectures:

On January 5, 1527, at three o'clock in the cold, fading light of a winter afternoon, Felix Manz was led from the prison cell and taken to the edge of the Limmat River. His hands and feet were bound and his hands were pulled over his knees, and a wooden stake was placed behind his knees to restrain him in a fetal position. He was taken by boat to the middle of the river and the hooded executioner...held him underwater until he was dead by drowning.

Without becoming too much like the writer of a science fiction horror novel, I emphasize the details of executions of early Anabaptists to get across to my students how much of Europe consisted of sites of gruesome conflict and violence rather than peaceful and pleasant places of happy and content peasants. It is the realistic context in which the Amish and other Plain Anabaptist groups who are still around today developed, and it takes a good history book, like Yoder's, to find the right descriptions to make those points both dramatically and educationally to students. 


\section{Brief Concluding Remarks}

Each of these 11 books (six reviewed in Part 1 and five reviewed in Part II) are ones that I would like to read again, and likely will! Each taught me things that I could apply in an educational setting; hence, the focus of this review essay is on lessons for lectures for both the in-class and online versions of my Amish Society course. Other readers can adopt a different view of each

book, but likewise learn much that is new or that reminds and reinforces for them what they already knew.

\section{References}

Lepley, S. (2019, May 30). 9 mind-blowing facts about the US farming industry. Business Insider. https://markets.businessinsider.com/news/stocks/farming-industry-facts-us-2019-51028242678\#

Nolt, S. (2016). The Amish: A concise introduction. Johns Hopkins University Press.

U.S. Bureau of Labor Statistics. (2016). High-income households spent half of their food budget on food away from home in 2015. https://www.bls.gov/opub/ted/2016/high-incomehouseholds-spent-half-of-their-food-budget-on-food-away-from-home-in-2015.htm

World Bank. (2019, July 15). Rural population (\% of total population). https://data.worldbank.org/indicator/SP.RUR.TOTL.ZS 